\title{
PENGARUH MODEL GROUP INVESTIGATION BERBASIS INTERNET TERHADAP HASIL BELAJAR DAN KEMAMPUAN DIGITAL LITERASI SISWA
}

\author{
M. Sai \\ Program Pascasarjana Pendidikan IPS Universitas Negeri Surabaya \\ muhsai75@gmail.com
}

\begin{abstract}
Abstrak
Tujuan penelitian ini adalah untuk menganalisis: (1) perbedaan antara siswa yang mengikuti pembelajaran group investigation berbasis internet dengan siswa yang mengikuti pembelajaran group investigation berbasis perpustakaan terhadap peningkatan hasil belajar siswa; (2) perbedaan antara siswa yang mengikuti pembelajaran group investigation berbasis internet dengan siswa yang mengikuti pembelajaran group investigation berbasis perpustakaan terhadap peningkatan kemampuan digital literasi siswa. Jenis penelitian ini adalah quasi experiment dengan non-equivalent control group design. Variabel dalam penelitian ini meliputi variabel bebas berupa model pembelajaran group investigation dan variabel moderator yakni berbasis internet, serta variabel terikat berupa kemampuan digital literasi siswa. Populasi dalam penelitian ini adalah siswa SMP KHM. Nur Surabaya, dengan sampel siswa kelas 8-A dan 8-C. Instrumen yang digunakan adalah soal pretest dan posttest kemampuan materi IPS. Teknik analisis data menggunakan uji anova dua jalur dan uji independent sample t-test (dengan taraf signifikansi 5\%). Hasil penelitian menunjukkan bahwa: (1) peningkatan hasil belajar siswa yang memperoleh pembelajaran group investigation berbasis internet lebih tinggi daripada siswa memperoleh pembelajaran group investigation berbasis perpustakaan; (2) peningkatan kemampuan digital literasi siswa yang memperoleh pembelajaran group investigation berbasis internet lebih tinggi daripada siswa memperoleh pembelajaran group investigation berbasis perpustakaan.
\end{abstract}

Kata kunci: model pembelajaran group investigation berbasis internet, hasil belajar, kemampuan digital literasi

\section{THE EFFECT OF INTERNET-BASED GROUP INVESTIGATION MODEL ON STUDENTS' LEARNING OUTCOME AND DIGITAL LITERACY ABILITY}

\author{
M. Sai \\ Program Pascasarjana Pendidikan IPS Universitas Negeri Surabaya \\ muhsai75@gmail.com
}

\begin{abstract}
The purpose of this study was to analyze: (1) the difference between students who take internetbased learning group investigation with students who take the group investigation learning library based on improving student learning outcomes; (2) the difference between students who take internetbased learning group investigation with students following study group investigation based library of digital literacy to increase the ability of students. This research is a quasi experiment with non equivalent control group design. The variables in this study included the independent variable in the form of model of learning and investigation group namely internet-based moderator variable and the dependent variable of the ability of digital literacy of students. The population in this study were junior high school students KHM. Nur Surabaya, with a sample of students in grade $8-A$ and $8-C$. The instrument used is a matter of pretest and posttest material capabilities IPS. While the data collection techniques used are observation and questionnaire digital literacy ability of students.Data were analyzed using ANOVA test and test two paths independent sample $t$ - test (with significance level of 5 $\%)$. The results showed that the use of moderator variables in the form of internet access affect the learning outcomes and digital literacy capabilities so the result is: (1) Increasing the learning outcomes of students who received internet-based learning group investigation is higher than the students obtain a library-based learning group investigation. (2) Increasing the capability of digital literacy of students who received internet-based learning group investigation is higher than the students obtain a librarybased learning group investigation.
\end{abstract}

Keywords: learning model of group investigation internet-based, learning outcomes, the ability of digital literacy 


\section{Pendahuluan}

Memanfaatkan internet sebagai sumber belajar dalam pembelajaran IPS berarti mengenalkan kesadaran siswa pada dunia globalisasi secara langsung sebagai pengalaman dalam struktur kognitif. Ini melibatkan penggalian pengalaman dari pembelajaran yang bermakna. Teknologi digital saat ini memungkinkan untuk menangkap dunia melalui gambar, suara, urutan audiovisual atau animasi dan untuk merakit dan menyajikan semua ini dengan atau tanpa teks. Dengan cara ini anak-anak dari segala usia dan kemampuan dapat terlibat dengan dunia dan membuat makna mereka sendiri. Inilah sebabnya mengapa kita perlu memahami digital literasi dan menghubungkannya dengan proses pembelajaran (Rusman, 2012, p. 309-310).

Kemampuan digital literasi adalah kemampuan untuk mencari, membaca dan melihat kumpulan data dari internet, kemudian menuliskannya melalui komputer menggunakan aplikasi pengolah kata standar yakni Microsoft Word. Dengan kemampuan digital literasi siswa dituntut untuk menerapkan keterampilan menghubungkan, menafsirkan dan memahami seluk-beluk dunia dan lingkungan sosial di mana siswa tinggal berdasarkan informasi yang mereka peroleh dari internet. Dalam pandangan (Nair et al., 2012, p. 75), kemampuan literasi komputer (digital literasi) ini diperlukan karena dengan ketrampilan literasi yang kuat siswa memiliki alat utama melihat dan menginterpretasikan informasi yang terkait dengan tema pelajaran dan bahkan berbagai hal dalam kehidupannya.

Kemampuan literasi secara umum berarti melibatkan kegiatan membaca, berbicara, mendengarkan, dan menulis. Siswa SMP/MTs harus diperkenalkan sejak dini dengan komputer dan internet di lingkungan sekolah, sebagai peralatan utama dalam dunia digital sehingga siswa telah mengadaptasi perubahan zaman secara progesif dan positif (Rusman, 2012, pp. 306-307). Kemampuan literasi siswa sangat vital dalam proses belajar mengajar karena di dalamnya proses dialektis yang membangun perbaikan-perbaikan ilmiah dan tumbuhnya inovasi. Literasi tidak harus diajarkan oleh guru bahasa tapi semua guru disiplin ilmu. Tugas penting guru pada abad ini yakni memfasilitasi pembelajaran digital literasi guna menopang pencapaian ilmu pengetahuan dan teknologi.

Kemampuan digital literasi siswa SMP KHM. Nur Surabaya masih sederhana. Ini dikarenakan pihak sekolah tidak memberi pembelajaran berbasis komputer. Meskipun ada pelajaran TIK (Teknologi Informasi dan Komputer) tetapi pelajaran tersebut masih berbasis teori. Laboratorium komputer pun juga ada namun masih belum dimanfaatkan secara sistematis. Laboratorium komputer tersebut dimanfaatkan oleh pihak MI (Madrasah Ibtidaiyah) karena SMP KHM. Nur Surabaya menjadi satu gedung dengan MI yang juga satu naungan yayasan. Siswa-siswi SMP KHM. Nur sedikit mengerti tentang internet dan kemampuan mengetik bukan dari bangku SMP tapi sudah sejak dari MI/SD, atau temanteman pergaulannya di rumah. Jadi kemampuan browsing tidak mereka peroleh dari sekolah tapi dari luar sekolah SMP. Selain itu, pembelajaran yang menerapkan model pembelajaran kooperatif seperti group investigation juga belum pernah dilakukan. Pembelajaran yang ada masih menggunakan model konvensional.

Dengan demikian pembelajaran berbasis internet diharapkan dapat meningkatkan kemampuan digital literasi siswa karena mengarahkan siswa untuk mengadaptasi perubahan dan perkembangan teknologi yang pada gilirannya menjadi mahluk sosial yang tumbuh sebagai bagian dari masyarakat. Keseimbangan seperti ini diperlukan dalam pengembangan kurikulum. Zhang (2013, p. 48) berpendapat siswa memerlukan berbagai kemahiran untuk membantu proses belajar seperti memanfaatkan teknologi informasi. Dengan perkembangan teknologi, itu jauh lebih mudah untuk mengembangkan beberapa keahlian. Siswa memiliki kesempatan untuk menggunakan internet di dalam kelas seharihari. Ini adalah era digital, sehingga teknologi dapat bermanfaat pada siswa. Peningkatan kemampuan digital literasi siswa juga bisa terjadi melalui gaya mengajar bervariasi, membaca novel online, menulis makalah, membuat proyek, dan membuat presentasi kelompok. Siswa harus tidak hanya diajarkan satu cara meningkatkan kemampuan digital literasi. Beberapa variasi strategi dalam rangka meningkatkan kemampuan digital literasi bisa dilakukan. 
Proses pembelajaran dalam kelas menjadi menarik dan menyenangkan apabila guru IPS menggunakan salah satu di antara dua alat bantu pembelajaran yakni penggunaan media dan model pembelajaran yang relevan. Sebaliknya pembelajaran IPS menjadi pelajaran yang membosankan dan tidak menarik jika guru IPS tidak berusaha memanfaatkan dua alat bantu tersebut. Penggunaan media dan model mutlak diperlukan untuk memperjelas permasalahan dan solusi pada tema ajar, memberi motivasi belajar, menumbuhkan kemampuan berpikir kritis, dan selanjutnya meningkatkan kemampuan digital literasi siswa (Hamzah, 2010, p. 45).

Untuk mewujudkan hasil belajar IPS diperlukan sebuah penilaian yang komprehensif. Mardapi (2008, p. 6) berpendapat bahwa penilaian mencakup semua cara yang digunakan untuk menilai unjuk kerja individu, berfokus pada individu yaitu prestasi belajar yang dicapai oleh individu. Penilaian harus mampu mendorong peserta didik belajar lebih baik dan guru untuk mengajar lebih baik. Uno \& Koni $(2012$, p. 156) mengemukakan indikator keefektifan pembelajaran biasanya diukur dengan tingkat pencapaian siswa yang diketahui setelah mengikuti pembelajaran dan evaluasi.

Dari kedua pendapat tersebut, untuk menentukan peningkatan hasil belajar maka tidak hanya satu faktor saja yang dilihat dari siswa. Tetapi juga harus memperhatikan nilainilai pada faktor-faktor yang lainnya terkait proses yang dilakukan untuk pencapaian nilai tersebut (Wibowo \& Marzuki, 2015).

Sedangkan kaitan dengan kemampuan digital literasi, maka tujuan dalam pembelajaran IPS adalah agar siswa mampu memahami tema dari banyak sumber yang ada di internet. Mengantarkan siswa pada pengayaan tema, menambah wawasan dan khazanah kalimat dalam bentuk konsep, idiom, dan kalimat sekaligus melatih siswa menyusun makalah ilmiah dan mempresentasikannya. Hal ini tersusun berurutan sebagaimana terdapat dalam langkah-langkah pembelajaran dalam group investigation.

Pembelajaran yang sesuai dengan karakteristik mata pelajaran IPS adalah pembelajaran yang menghubungkan siswa dengan kehidupan dunia nyata (Jamrut \& Aman, 2014, p. 143). Dalam pembelajaran group investigation, siswa dilatih berinteraksi dalam kelompok sehingga mampu menyelesaikan tugas bersama, dan hasil yang dicapai akan dirasakan kebaikannya oleh semua anggota masing-masing. Kemampuan bekerja sama dalam kelompok memiliki relevansi yang kuat dengan tujuan pembelajaran IPS yakni menjadikan siswa menjadi warga negara yang baik dan bagian utuh dari masyarakat (Jongsermtrakoon \& Nasongkhla, 2015, p. 784).

Peningkatan kemampuan literasi juga bisa dimunculkan melalui penerapan tipe pembelajaran kooperatif dengan berbagai varian-variannya. Karena pembelajaran kooperatif membagi siswa dalam kelompok-kelompok kecil untuk bekerja sama. Rendahnya kemampuan digital literasi siswa bisa jadi dikarenakan pembelajaran yang bersifat monoton, siswa hanya mendengarakan dan mencatat apa yang dijelaskan oleh guru, dan tidak memberikan kesempatan kepada siswa untuk mengkonstruksi dan mengembangkan pengetahuannya sendiri melalui diskusi dan kerja sama.

Penerapan pembelajaran group investigation pada tema Masa Kependudukan Jepang dan Persiapan Kemerdekaan Indonedia dalam pembelajaran IPS kelas VIII ini sangat relevan dan kongruen dengan pendekatan saintifik dalam Kurikulum 2013. Model pembelajaran ini menuntut siswa untuk berani melakukan investigasi kelompok, memiliki kemampuan berkomunikasi maupun dalam keterampilan proses kelompok (group process skills) (Nurhadi, 2003, p. 64). Penggunaaan pembelajaran group investigation berbasis internet diharapkan dapat meningkatkan hasil belajar dan kemampuan digital literasi siswa sehingga siswa mendapatkan pengetahuan yang memadai.

Dalam penerapan pembelajaran group investigation ini ditopang dengan pemanfaatan internet sekolah supaya siswa terbiasa dengan penggunaan refrensi yang kredibel dan relevan dengan tema yang sedang dibahas yakni Masa Kependudukan Jepang dan Persiapan Kemerdekaan Indonesia.

Pembelajaran group investigation inimerupakan salah satu bentuk pembelajaran kooperatif yang menekankan pada aktivitas siswa untuk mencari sendiri tema (informasi) pelajaran yang akan dipelajari melalui bahanbahan yang tersedia, misalnya dari buku pelajaran atau siswa dapat mencari melalui 
internet dan perpustakaan. Siswa dilibatkan sejak perencanaan, baik dalam menentukan tema maupun cara untuk mempelajarinya melalui investigasi. Tipe pembelajaran ini menuntut para siswa untuk memiliki kemampuan yang baik dalam berkomunikasi maupun dalam keterampilan proses kelompok. Keterlibatan siswa secara aktif dapat terlihat mulai dari tahap pertama sampai tahap akhir pembelajaran.

Menurut Slavin (2005, p. 218) dalam group investigation para murid bekerja melalui enam tahap, yaitu: grouping, planning, investigation, organizing, presenting, dan evaluating. Sedangkan pengembangan tipe pembelajaran kooperatif group investigation berupa siswa harus berbagi informasi mengenai tema pokok yang disajikan oleh guru sehingga diperoleh subtema mengenai gagasan baru yang selanjutnya tiap kelompok harus mencari solusi dalam menyelesaikan permasalahan tersebut. Setelah melakukan perencanaan, investigasi tiap kelompok mempresentasikan hasil penelitian kelompok, dalam kegiatan persentasi semua anggota kelompok harus mengemukakan pendapat dan menjawab pertanyaan dari kelompok lain secara merata. Jenis evaluasi yang digunakan adalah penilaian autentik karena sesuai dengan kurikulum 2013. Penilaian autentik tersebut berupa lembar penilaian keterampilan berupa lembar pengamatan keterampilan sosial yang dilakukan pada saat proses pembelajaran berlangsung dan tes pilihan jamak untuk mengetahui perbedaan nilai sebelum dan sesudah kegiatan pembelajaran.

Pemanfaatan internet dalam pembelajaran group investigation ini dilakukan pada tahap ketiga yakni tahap penyelidikan (investigation). Dalam upaya melakukan penyelidikan siswa diharuskan mencari sumber yang akurat guna menopang substansi masalah. Pada saat siswa melakukan investigasi di perpustakaan secara tidak langsung mereka menyadari pentingnya perpustakaan sebagai sarana pendukung pembelajaran utama di lingkungan sekolah.

Fungsi internet ini adalah sebagai penopang dalam mendapatkan data dari tema dan permasalahan yang dihadapi. Pemanfaatan internet ini bertujuan untuk melatih siswa bahwa dalam memahami permasalahan sosial dibutuhkan sumber data yang akurat, konsep dan teori-teori yang berhubungan.
Dalam penelitian ini digunakan teoriteori yang relevan dan mendukung yakni teori belajar konstruktivis John Dewey dan Lev Vygotsky. Kedua teori ini sangat relevan dengan gejala yang ada dalam penelitian ini.

Pertama, Konsep pendidikan yang diusung oleh John Dewey ini dikenal dengan pendidikan progresivisme yaitu pendidikan yang dijalankan secara demokratis. Demokratis dalam pendidikan bermakna bahwa penyelenggaraan pendidikan di sekolah, siswa harus berperan aktif dalam proses belajar ataupun dalam menentukan materi pelajaran (Iman, 2004, p.3). Proses ini sejalan dengan langkah-langkah yang ada dalam pembelajaran group investigation, di mana siswa menentukan sendiri materi/topik yang akan dipelajari dengan tuntunan guru.

Lebih lanjut Rostitawati (2014, p. 18), menjelaskan bahwa pola pemikiran Dewey tentang pendidikan didasarkan pada filsafat instrumentalisme (pragmatisme), dimana konsep-konsep dasar pengalaman (experience), pertumbuhan (growth), eksperimen (experiment), dan transaksi (transaction) berdialektis dalam kognisi siswa. Pendidikan dan filosofi saling membutuhkan satu sama lain; dimana tanpa filosofi, pendidikan kering akan arahan inteligensi. Sebaliknya, tanpa pendidikan, filosofi kehilangan implementasi praktis dan menjadi mandul. Pengalaman merupakan basis dari keduanya, dimana pendidikan didefinisikan sebagai rekonstruksi dan reorganisasi dari pengalaman yang memberi tambahan pada arti pengalaman, dan yang meningkatkan kemampuan untuk mengarahkan pengalaman berikutnya.

Kedua, dalam pandangan Vygotsky perkembangan dan pembelajaran terjadi di dalam konteks sosial, yakni di dunia yang penuh dengan orang yang berinteraksi dengan anak sejak anak itu lahir. Orang-orang inilah yang sangat berperan dalam membantu anak belajar dengan menunjukkan benda-benda, dengan berbicara sambil bermain, dengan membacakan ceritera, dengan mengajukan pertanyaan dan sebagainya. Dengan kata lain, orang dewasa menjadi perantara bagi anak dan dunia sekitarnya. Kemampuan belajar lewat instruksi dan perantara adalah ciri inteligensi manusia (Adam, 2014, p. 225). Ada tiga elemen dasar dalam teori belajar Vygotsky yakni peranan interaksi sosial, Zone of Proximal Development (ZPD), dan scaf- 
folding. Masing-masing elemen tersebut terbukti implememtatif dalam penelitian ini.

Adapun manfaat yang dapat dipetik melalui penelitian ini adalah (1) manfaat teoretis yaitu bagi pengembang teori pembelajaran, hasil penelitian ini diharapkan dapat bermanfaat sebagai rujukan dan bahan pertimbangan untuk meningkatkan sikap sosial dan hasil belajar siswa. Selain itu, hasil penelitian ini memberikan eksplanasi yang rinci tentang keunggulan model pembelajaran kooperatif group investigation berbasis internet dengan tujuan meningkatkan hasil belajar siswa. dan (2) manfaat praktis yaitu bagi guru, sekolah, dan praktisi pendidikan maupun peneliti lainnya.

Adapun rumusan masalah yang akan menuntun penelitian ini ada dua yakni pertama, adakah pengaruh hasil belajar siswa antara siswa yang mengikuti model pembelajaran group investigation berbasis internet dengan siswa yang mengikuti model pembelajaran group investigation berbasis perpustakaan. Dan kedua adakah pengaruh kemampuan digital literasi siswa yang mengikuti model pembelajaran group investigation berbasis internet dengan siswa yang mengikuti model pembelajaran group investigation berbasis perpustakaan. Berdasarkan uraian tersebut penelitian ini bertujuan untuk menganalisis: (1) perbedaan antara siswa yang mengikuti pembelajaran group investigation berbasis internet dengan siswa yang mengikuti pembelajaran group investigation berbasis perpustakaan terhadap peningkatan hasil belajar siswa; (2) perbedaan antara siswa yang mengikuti pembelajaran group investigation berbasis internet dengan siswa yang mengikuti pembelajaran group investigation berbasis perpustakaan terhadap peningkatan kemampuan digital literasi siswa.

\section{Metode Penelitian}

Penelitian ini merupakan penelitian eksperimen kuasi. Dengan menggunakan desain pretes-postes grup kontrol tanpa acak (non randomized control group pretest posttest design). Desain eksperimen ulang non-random dipilih karena kedua kelas yang telah dipilih memiliki kemampuan awal yang setera. Pada penelitian ini peneliti melakukan pretes sebelum memberikan perlakuan dan melakukan postes setelah memberikan per- lakuan. Dalam desain eksperimen ini, terdapat kelompok eksperimen dan kelompok kontrol serta penetapan sampel yang tidak dilakukan secara random.

Populasi dalam penelitian ini adalah seluruh siswa kelas VIII SMP KHM. Nur Surabaya Tahun Pelajaran 2015/2016 yang terdiri dari 3 kelas. Adapun jumlah seluruh siswa Kelas VIII SMP KHM. Nur Surabaya adalah 93 siswa.Kemudian kelas VIII A sebagai kelas eksperimen dan 32 siswa kelas VIII C sebagai kelas kontrol.

Teknik pengumpulan data yang akan digunakan pada penelitian ini adalah tes dan observasi. Tes yang digunakan ada dua macam, pertama tes materi Masa Pendudukan Jepang dan Persiapan Kemerdekaan Indonesia. Kedua, tes kemampuan digital literasi. Teknik tes ini digunakan untuk mengumpulkan data yang berkaitan dengan hasil belajar dan kemampuan digital literasi siswa baik pretes maupun postes.

Teknik selanjutnya adalah observasi. Observasi dilakukan pada saat presentasi kelompok (tahap kelima). Ada dua aspek yang diobsrvasi pada tahap ini yaitu aspek kemampuan menjelaskan materi dan aspek menjawab pertanyaan secara argumentatif.

Tes

Tes yang diberikan dalam penelitian ini ada dua, yang pertama tes kemampuan IPS pada tema Masa Pendudukan Jepang dan Persiapan Kemerdekaan Indonesia ini berupa tes pilihan ganda sebanyak dua puluh butir soal yang diberikan pada saat pretes dan postes. Pretes dan postes diberikan pada kelas eksperimen dan kelas kontrol. Pretes diberikan di awal kegiatan penelitian dan hasil pretes akan digunakan untuk mengukur kemampuan awal siswa. Sedangkan postes diberikan di akhir kegiatan penelitian dan hasil postes ini digunakan untuk melihat peningkatan keterampilan sosial siswa baik di kelas eksperimen maupun kelas kontrol.

Dan yang kedua adalah tes kemampuan digital literasi. Tes ini juga sebanyak dua puluh butir soal dengan bentuk pilihan ganda. Untuk memperoleh skor tes digital literasi siswa, maka disusun pedoman penskoran yang dimodifikasi dari Facione (Somakim, 2010: 83), disajikan pada Tabel 1. 
Tabel 1. Pedoman Penskoran

\begin{tabular}{|c|c|c|c|c|c|}
\hline \multirow{2}{*}{ Aspek yang diukur } & \multirow{2}{*}{ Respon Siswa terhadap Soal } & \multicolumn{4}{|c|}{ Skor } \\
\hline & & 1 & 2 & 3 & 4 \\
\hline \multirow{3}{*}{ Pengetahuan konsep } & 1.Mengerti konsep-konsep sosial sederhana & & & & \\
\hline & 2.Memperhatikan istilah asing & & & & \\
\hline & 3.Menanyakan konsep yang belum dimengerti & & & & \\
\hline \multirow{3}{*}{$\begin{array}{l}\text { Penggunaan pengetahuan } \\
\text { IPS dalm menganalisis teks }\end{array}$} & 1.Menjawab soal dengan tepat berdasarkan pengetahuan IPS & & & & \\
\hline & 2.Mengkritisi dengan sederhana data yang relevan dengan materi & & & & \\
\hline & $\begin{array}{l}\text { 3.Mengerti kata-kata kunci empat disiplin ilmu yang terintegrasi } \\
\text { dalam IPS }\end{array}$ & & & & \\
\hline \multirow{5}{*}{$\begin{array}{l}\text { Menganalisis dan } \\
\text { mengevaluasi data atau } \\
\text { peristiwa }\end{array}$} & $\begin{array}{l}\text { 1.Peka terhadap topik sejarah yang berkaitan dengan materi masa } \\
\text { pendudukan Jepang dan persiapan kemerdekaan Indonesia }\end{array}$ & & & & \\
\hline & 2.Mampu mengenali tokoh dan peranannya terkait materi tersebut & & & & \\
\hline & 3.Mencermati waktu dan tempat setiap peristiwa terkait materi & & & & \\
\hline & $\begin{array}{l}\text { 4.Menuliskan peristiwa yang tidak terdapat dalam buku teks sebagai } \\
\text { bahan pengayaan }\end{array}$ & & & & \\
\hline & 5.Menanyakan pada guru materi yang relevan dengan topik & & & & \\
\hline \multirow{4}{*}{ Memecahkan masalah } & 1.Mampu mencari data dari internet dengan tepat & & & & \\
\hline & 2.Siswa mampu memilah data yang akan digunakan dan yang tidak & & & & \\
\hline & 3. Siswa menjawab pertanyaan dengan benar pada sesi presentasi & & & & \\
\hline & 4.Siswa mampu menuliskan kesimpulan & & & & \\
\hline
\end{tabular}

Sumber: modifikasi dari Yuni Pantiwati dan Husaman. (2011). Analisis Kemampuan Sains Siswa SMP Kota Malang

Analisis data hasil penelitian hasil belajar dan kemampuan digital literasi dilakukan dengan menggunakan analisis deskriptif dan analisis infrensial. Analisis deskriptif digunakan untuk mendeskripsikan sebaran data. Sedangkan analisis inferensial yang digunakan untuk menguji hipotesis adalah uji independent $t$ test. Terkait dengan statistik yang digunakan untuk analisis data dalam penelitian ini, maka pengujian persyaratan analisis yang dilakukan adalah uji normalitas dan uji homogenitas.

\section{Hasil Penelitian Dan Pembahasan}

\section{Analisis Deskriptif}

Perhitungan ukuran sentral yaitu mean, modus, median, serta standar deviasi tiap kelompok data dapat dilihat pada Tabel 2.

Berdasarkan Tabel 2, dapat dikemukakan nilai hasil belajarberbasis internet diperoleh nilai minimal sebesar 50, nilai maksimal sebesar 90, nilai rata-rata (mean) sebesar 72,81, nilai tengah (median) sebesar 74,50, nilai sering muncul (modus) sebesar 78 dengan simpang baku (std. Deviation) sebesar 9,441 . Dan penilaian pretest kelas eksperimen presentase tertinggi diperoleh pada kelas interval (50-56) dengan kategori cukup yaitu
$28,1 \%$. Sedangkan, pada penilaian posttest presentase tertinggi diperoleh pada kelas dua interval yaitu interval (66-73) dengan kategori cukup yaitu 34,375 \% dan interval (74-81) dengan kategori cukup yaitu $37,5 \%$.

Tabel 2. Standar Deviase tiap Kelompok Data

\begin{tabular}{lcc}
\hline Statistik & \multicolumn{2}{c}{ Hasil Belajar } \\
& $\begin{array}{c}\text { Berbasis } \\
\text { Internet }\end{array}$ & $\begin{array}{c}\text { Berbasis } \\
\text { Perpustakaan }\end{array}$ \\
\hline $\mathrm{N}$ & 32 & 32 \\
Rata-rata & 72,81 & 65,00 \\
Median & 74.50 & 65,00 \\
Modus & 78 & 55 \\
Standar Deviasi & 9.441 & 10,937 \\
Skor Minimum & 50 & 44 \\
Skor Maksimum & 90 & 90 \\
Banyak Kelas & 6 & 6 \\
Pajang Kelas & 9 & 9 \\
\hline
\end{tabular}

Sedangkan untuk kelas berbasis perpustakaan diperoleh nilai minimal sebesar 44, nilai maksimal sebesar 90 , nilai rata-rata (mean) sebesar 65, nilai tengah (median) sebesar 65, nilai sering muncul (modus) sebesar 55 dengan simpang baku (std. Deviation) sebesar 10,937. Dan presentase tertinggi diperoleh pada dua kelas yakni 
interval (29-37) dengan kategori rendah yaitu $25 \%$ dan interval (47-55) dengan kategori cukup yaitu $25 \%$. Sedangkan, pada penilaian posttest presentase tertinggi juga diperoleh pada dua kelas yakni interval (52-59) dengan kategori rendah yaitu 25\% dan interval (6875) dengan kategori cukup yaitu $25 \%$.

Sementara itu hasil observasi kemampuan digital literasi siswa dapat dilihat dari Tabel 3.

Tabel 3. Hasil Observasi

\begin{tabular}{|c|c|c|c|c|c|}
\hline \multirow{3}{*}{ No } & \multirow{3}{*}{ Jenis Ketrampilan } & \multicolumn{4}{|c|}{ Pertemuan } \\
\hline & & I & I & II & II \\
\hline & & Eksp & Kntr & Eksp & Kntr \\
\hline 1 & $\begin{array}{l}\text { Pengetahuan tentang } \\
\text { browsing internet } \\
\text { dengan keyword } \\
\text { "masa pendudukan } \\
\text { Jepang". }\end{array}$ & $74 \%$ & & $87 \%$ & \\
\hline 2 & $\begin{array}{l}\text { Pengetahuan tentang } \\
\text { mengoperasikan } \\
\text { komputer/laptop }\end{array}$ & $45 \%$ & & $92 \%$ & $80 \%$ \\
\hline 3 & $\begin{array}{l}\text { Pengetahuan tentang } \\
\text { tata cara mengetik di } \\
\text { microsoft word dan } \\
\text { cara melakukan } \\
\text { print out }\end{array}$ & $40 \%$ & & $84 \%$ & $81 \%$ \\
\hline 4 & $\begin{array}{l}\text { Browsing internet } \\
\text { materi masa } \\
\text { pendudukan Jepang } \\
\text { dan Persiapan } \\
\text { Kemerdekaan } \\
\text { Indonesia termasuk } \\
\text { video pembacaan } \\
\text { teks proklamasi oleh } \\
\text { Bung Karno }\end{array}$ & $60 \%$ & & $95 \%$ & \\
\hline \multirow[t]{3}{*}{5} & $\begin{array}{l}\text { Menyusun } \\
\text { rangkuman yang } \\
\text { diketik di microsoft } \\
\text { word secara } \\
\text { kelompok }\end{array}$ & & & $100 \%$ & $100 \%$ \\
\hline & & & mlah & 458 & 261 \\
\hline & & Rat & -rata & $91.6 \%$ & $87 \%$ \\
\hline
\end{tabular}

$=$ tidak dilakukan dalam pembelajaran

Berdasarkan data yang disajikan pada di atas dapat terlihat bahwa pada pertemuan I, masing-masing kelompok tidak memiliki kemampuan digital literasi karena belum ada perlakuan apapun. Pengukuran kemampuan digital literasi pada pertemuan I ini dilakukan melalui observasi terukur. Pada pertemuan II persentase siswa yang memiliki kemampuan digital literasi pada kelompok eksperimen lebih tinggi dibandingkan kelompok kontrol. Pada pertemuan II kelompok eksperimen hampir seluruh kelompok (6 kelompok) mampu melakukan keterampilan digital literasi dengan lebih baik daripada pertemuan I. Ini menandakan bahwa perlakuan (treatment) yang diberikan memberi dampak pada peningkatan digital literasi secara signifikan karena persentase jumlah siswa yang memiliki kemampuan digital literasi pada kelas eksperimen berada di antara $87 \%-100 \%$.

Sedangkan pada kelompok kontrol kemampuan digital literasinya lebih rendah karena persentase jumlah siswa yang memiliki kemampuan tersebut berada di antara $80 \%$ $100 \%$. Pada aspek menyusun rangkuman yang diketik di microsoft word secara kelompok baik kelas eksperimen maupun kelas kontrol prosentasinya sama-sama mencapai $100 \%$ karena semua kelompok (6 kelompok) mengumpulkan tugas rangkumannya sesuai dengan topik yang diberikan.

Pada pertemuan II kelompok eksperimen dan kelompok kontrol mempresentasikan data hasil investigasi di depan siswa lain secara bergiliran. Presentasi kelompok ini disertai diikuti dengan sesi tanya jawab. Selanjutnya ditutup dengan evaluasi oleh guru. Evaluasi dilakukan terhadap pertanyaan-pertanyaan yang tidak terjawab atau jawaban yang berkembang pada saat diskusi. Pembelajaran ditutup dengan pengumpulan tugas rangkuman. Tugas rangkuman tersebut dapat dilihat pada Tabel 4 .

Tabel 4. Penilaian Tugas Ringkasan (resume) Siswa Kelas Eksperimen dan Kelas Kontrol (\%)

\begin{tabular}{llcc}
\hline No & Aspek yang Dinilai & $\begin{array}{c}\text { Kelas } \\
\text { Eksperimen }\end{array}$ & $\begin{array}{c}\text { Kelas } \\
\text { Kontrol }\end{array}$ \\
\hline 1 & Ukuran kertas A4 & $100 \%$ & $90 \%$ \\
2 & Ukuran font 12 & $50 \%$ & $50 \%$ \\
3 & Menggunakan jarak 2 spasi & $70 \%$ & $70 \%$ \\
4 & Jumlah maksimal 6 lembar & $100 \%$ & $80 \%$ \\
5 & Menggunakan tata penulisan & $80 \%$ & $50 \%$ \\
& yang benar (seperti pengguna- & & \\
& an huruf besar dan kecil). & & \\
6 & Ringkasan sesuai dengan topik & $100 \%$ & $90 \%$ \\
& yang diberikan & & \\
7 & Materi yang dimasukkan & $90 \%$ & $80 \%$ \\
& dalam ringkasan termasuk & & \\
point yang penting & Mencantumkan sumber & $60 \%$ & $80 \%$ \\
& bacaan (daftar pustaka) & & \\
& Rata-Rata & $81,25 \%$ & $73,75 \%$ \\
\hline
\end{tabular}


Tabel 4 menjelaskan bahwa hasil penilaian tugas membuat ringkasan kelas eksperimen dan kelas kontrol berbeda. Kelas eksperimen sedikit lebih unggul dalam prosentase dibanding kelas kontrol. Keunggulan kelas eksperimen tampak pada semua aspek selain aspek mencamtumkan sumber bacaan. Pada aspek ini justru kelas kontrol lebih reliabel karena mencamtumkan sumber bacaan dengan prosentase mencapai $80 \%$. Sedangkan pada aspek ukuran font 12 dan menggunakan jarak 2 spasi prosentasenya sama besar yakni 50\% dan $70 \%$.

Hal ini menunjukan bahwa pemberian perlakuan (treatment) pada kelas eksperimen yaitu dengan menerapkan model pembelajaran group investigation berbasis internet terbukti lebih mampu dalam meningkatkan kemampuan digital literasi siswa daripada kelas kontrol yang menerapkan model pembelajaran group investigation berbasis perpustakaan. hal ini terbukti dari nilai kelas eksperimen yang lebih tinggi sehingga kelas ini lebih mampu meningkatkan kemampuan digital literasi siswa dan dapat mengembangkan keterampilan tersebut pada tingkat yang lebih tinggi.

Dapat disimpulkan bahwa penerapan model pembelajaran group investigation berbasis internet berpengaruh signifikan terhadap kemampuan digital literasi siswa pada kelas eksperimen dan kelas kontrol. Namun peningkatan tersebut lebih efektif menggunakan model pembelajaran group investigation berbasis internet daripada menggunakan model pembelajaran group investigation berbasis perpustakaan.

\section{Pengujian Prasyarat}

Uji normalitas dimaksudkan untuk mengetahui apakah variabel-variabel dalam penelitian mempunyai sebaran distribusi normal atau tidak. Penghitungan uji normalitas ini menggunakan rumus KolmogorovSmirnov $Z$, dengan pengolahan menggunakan bantuan komputer program SPSS 16.0 for Windows dan didaptasikan bahwa nilai statistik hasil belajar IPS siswa dengan model pembelajaran group investigation berbasis internet adalah 0,731 dengan probabilitas 0,05 . Nilai Sig. pretest $>0,05$ atau lebih besar dari $\alpha$, dengan demikian $\mathrm{H}_{0}$ diterima, artinya data nilai pretest kelas eksperimen berasal dari populasi berdistribusi normal.
Sedangkan nilai statistik hasil belajar IPS dengan model pembelajaran group investigation berbasis perpustakaan adalah 0,43 dengan probabilitas 0,05. Nilai Sig. Pretest > 0,05 atau lebih besar dari $\alpha$, dengan demikian $\mathrm{H}_{0}$ diterima, artinya data nilai pretest dan posttest berasal dari populasi berdistribusi normal.Karena semua data berdistribusi normal maka analisis dapat dilanjutkan.

\section{Pengujian Hipotesis}

Uji hipotesis yang digunakan dalam penelitian ini adalah uji statistik parametrik, yaitu Independent Sample t-test. Uji ini digunakan untuk mengambil keputusan apakah hipotesis diterima atau ditolak.

\section{Hipotesis Pertama}

Hasil analisa uji t (t-test) hasil tes akhir (posttest) dapat diketahui bahwa nilai $\mathrm{t}$ hitung sebesar 14,697 dengan signifikansi 0,01 . Nilai signifikan yang menunjukkan 0,01 $<0,05$ maka Ho ditolak dan $\mathrm{H}_{1}$ diterima. Hal itu juga didukung oleh nilai mean kelas eksperimen sebesar 43,00 lebih besar daripada kelas kontrol sebesar 34,81. Penjelasan hasil pengujian tersebut dapast dilihat dari Tabel 5.

Tabel 5. Hasil Pengujian Hipotesis Hasil Belajar Siswa

\begin{tabular}{llcccccc}
\hline A & Kelas & $\mathrm{N}$ & Mean & $\mathrm{SD}^{2}$ & $\mathrm{t}_{\text {hitung }}$ & $\mathrm{t}_{\text {tabel }}$ & Sig. \\
\hline \multirow{2}{*}{0,05} & Eksperrimen & 32 & 86,25 & 5,024 & & & \\
& Kontrol & 32 & 63,56 & 7,750 & 14,697 & 2,0369 & 0,01 \\
\hline
\end{tabular}

Hasil analisa uji t (t-test) hasil tes akhir (posttest) dapat diketahui bahwa nilai $\mathrm{t}$ hitung sebesar 14,697 dengan signifikansi 0,01 . Nilai signifikan yang menunjukkan 0,01 $<0,05$ maka Ho ditolak dan $\mathrm{H}_{1}$ diterima. Hal itu juga didukung oleh nilai mean kelas eksperimen sebesar 43,00 lebih besar daripada kelas kontrol sebesar 34,81.

\section{Hipotesis Kedua}

Hasil analisa uji t ( $t$-test) hasil angket kemampuan digital literasi dari tabel di bawah ini. dapat diketahui bahwa nilai $\mathrm{t}$ hitung sebesar 16,269 dengan signifikansi 0,01. Nilai signifikan yang menunjukkan $0,01<0,05$ maka Ho ditolak dan $\mathrm{H}_{1}$ diterima. Hal itu juga didukung oleh nilai mean kelas eksperimen sebesar 87,44 lebih besar daripada kelas kontrol sebesar 67,50 . 
Tabel 6. Hasil Pengujian Hipotesis

Kemampuan Digital Literasi Siswa

\begin{tabular}{cccccccc}
\hline A & Kelas & N & Mean & SD2 & t-hitung & t-tabel & Sig. \\
\hline \multirow{2}{*}{0,05} & Eksperrimen & 32 & 87,44 & 3,222 & \multirow{2}{*}{16,269} & \multirow{2}{*}{2,0369} & 0,01 \\
& Kontrol & 32 & 67,50 & 6,138 & & & \\
\hline
\end{tabular}

Dari hasil pengujian di atas dapat disimpulkan bahwa ada pengaruh model pembelajaran group investigation berbasis internet terhadap kemampuan digital literasi siswa kelas VIII SMP KHM. Nur Surabaya tahun pelajaran 2015/2016.

Analisis deskriptif tentang hasil belajar IPS siswa dan kemampuan digital literasi siswa ditinjau dari pendekatan pembelajaran yang dipergunakan menunjukkan bahwa ratarata skor hasil belajar IPS siswa yang mengikuti pendekatan model pembelajarangroup investigation berbasis internetadalah 22,69 lebih besar dari siswa yang mengikuti pendekatan pembelajaran group investigation berbasis perpustakaan.

Demikian pula dengan rata-rata kemampuan digital literasi siswa yang mengikuti pendekatan model group investigation berbasis internet adalah 19,94 lebih besar dari siswa yang mengikuti pendekatan pembelajaran group investigation berbasis perpustakaan. Untuk itu dapat disimpulkan bahwa hasil belajar siswa dan kemampuan digital literasi siswa yang mengikuti model group investigation berbasis internet lebih baik dari pada siswa siswa yang mengikuti pendekatangroup investigation berbasis perpustakaan. Sehubungan dengan hal tersebut maka hipotesis nol (H0) ditolak dan menerima hipotesis penelitian yang menyatakan bahwa ada pengaruh yang signifikan pembelajaran group investigation berbasis internet terhadap kemampuan digital literasi siswa kelas VIII SMP KHM. Nur Surabaya tahun ajaran 2015/2016.

Pengaruh Group Investigation Berbasis Internet Terhadap Hasil Belajar

Analisis deskriptif tentang hasil belajar IPS tersebut ditinjau dari pendekatan pembelajaran yang dipergunakan menunjukkan bahwa rata-rata skor hasil belajar IPS siswa yang mengikuti pembelajaran group investigation berbasis internet adalah 86,25 lebih besar dari siswa yang mengikuti pembelajaran group investigation berbasis perpustakaan yaitu 63,56. Oleh karena itu dapat disimpulkan bahwa hasil belajar IPS siswa yang mengikuti model pembelajaran group investigation berbasis internet lebih baik dari pada hasil belajar IPS siswa yang mengikuti model pembelajaran pembelajaran group investigation berbasis perpustakaan.

Hasil analisis ini menunjukkan kesamaan dengan penelitian yang dilakukan Yuliani, dkk. (2013, p. 12) bahwa penerapan model group investigation memberi pengaruh yang signifikan terhadap hasil belajar IPS kelas IV SD dibanding dengan penerapan pembelajaran konvensional.Lebih lanjut Yuliani (2013, p. 11) menjelaskan bahwa peningkatan hasil belajar IPS dan sikap sosial siswa tersebut disebabkan karena penerapan pembelajaran group investigation yang diterapkan oleh guru. Karenanya guru harus secara selektif memilih pendekatan pembelajaran yang sesuai untuk pokok bahasan tertentu agar tujuan pembelajaran dapat tercapai. Guru dalam pembelajaran diharapkan tidak hanya mengembangkan ranah kognitif saja, tetapi juga harus mengembangkan ranah afektif dan psikomotor.

Peningkatan hasil belajar dengan menerapkan pembelajaran group investigation juga terjadi pada mata pelajaran PKn. Sulasti (2013, pp. 9-10) dalam penelitian tindakan kelasnya menyatakan bahwa setiap siklus terjadi peningkatan hasil belajar yang signifikan meskipun pada siklus I masih terdapat 14 siswa yang belum mencapai nilai KKM namun pada siklus III semua siswa dapat mencapai nilai KKM. Artini, Pasaribu, \& Husain (2015, p. 51) juga membuktikan bahwa dengan menerapkan pembelajaran group investigation juga terjadi peningkatan hasil belajar pada mata pelajaran IPA. Peningkatan hasil belajar tersebut meliputi aspek kognitif, afektif dan psikomotor. Termasuk tercapainya kriteria ketuntasan minimal secara klasikal, yang mana hal tersebut dipengaruhi oleh optimalnya aktivitas guru dan siswa selama proses pembelajaran menggunakan model group investigation.

Dalam penelitian lain, Trismanita (n.d, p. 6) juga menyatakan bahwa penerapan pembelajaran groupinvestigation berpengaruh signifikan terhadap hasil belajar siswa pada mata pelajaran IPA. Peningkatan hasil belajar tersebut dikarenakan adanya peningkatan aktivitas belajar yang dilakukan oleh siswa selama proses pembelajaran berlangsung. 
Aktivitas belajar siswa meningkat setelah menggunakan model pembelajaran group investigation karena selama proses pembelajaran siswa banyak melakukan aktivitas seperti bekerjasama dengan teman dalam menyelesaikan LKK, mempresentasikan hasil penyelidikan/diskusi kelompok serta mengajukan pertanyaan dan membuat kesimpulan mengenai materi tersebut.

Keberhasilan siswa SMP KHM. Nur Surabaya dalam meningkatkan hasil belajar IPS berhubungan erat dengan tiga item yakni proses pembelajaran yang diterapkan, penguasaan guru dalam kelas, dan keterlibatan siswa dalam pembelajaran. Hasil ini sejalan dengan apa yang dikemukakan oleh Slavin (2005, p. 57) yakni tujuan pembelajaran kooperatif adalah menciptakan situasi di mana keberhasilan individu ditentukan atau dipengaruhi oleh keberhasilan kelompoknya.

Pengaruh Group Investigation Berbasis Internet terhadap Kemampuan Digital Literasi

Hipotesis kedua menyatakan bahwa kemampuan digital iterasisiswa secara signifikan lebihtinggi yang mengikuti model pembelajaran group investigation berbasis internet dibandingkan dengan yang mengikuti model pembelajaran group investigation berbasis perpustakaan.

Data kemampuan digital literasi diambil dari dua penugasan yakni tes tulis dan hasil karya berupa rangkuman. Hasil analisis menunjukkan bahwa terdapat pengaruh yang signifikan mengenai kemampuan digital literasi antara siswa yang mengikuti model pembelajaran group investigation berbasis internet dengan siswa yang mengikuti model pembelajaran group investigation berbasis perpustakaan. Pengaruh itu bukan hanya ditunjukkan dari hasil tes dan karya namun juga pada mindset siswa, di mana siswa SMP KHM. Nur Surabaya kini telah menggunakan internet sebagai sumber belajar.

Sebelum adanya penerapan pembelajaran ini, siswa kelas VIII SMP KHM. Nur tidak memiliki kemampuan yang memadai mengenai digital literasi sehingga pembelajaran group investigation berbasis internet memberi pengetahuan positif bagi mereka dalam mengembangkan pengetahuan digital literasi untuk keperluan pembelajaran.

Hasil tes kemampuan digital literasi kelas eksperimen menunjukkan rata-rata
87.43, sedangkan kelas kontrol sebesar 67, 37 . Keduanya selisih 20, 06. Selisih ini cukup signifikan dalam menentukan kemampuan dan pengetahuan siswa mengenai digital literasi. Sementara itu data dari hasil karya kelas eksperimen sebesar 91,6 dan kelas kontrol sebesar 87.

Adanya peningkatan ini sejalan dengan pendapat yang dikemukakan oleh Alkalai (2004, p. 96;103) yang me-nyatakan bahwa penerapan konsep digital literasi dalam pembelajaran dapat menig-katkan pemahaman ketrampilan digital literasi itu sendiri dan juga meningkatkan komunikasi antar peserta didik. Lebih lanjut Alkalai dalam penelitiannya tersebut membuktikan bahwa anak-anak setingkat SD di Israel dapat lebih mudah memahami bahasa Inggris dengan menerapkan pembelajaran digital literasi (pp. 96-97).

Penelitian Keskin (2015, p. 15) juga menyimpulkan bahwa ketika penggunaan digital literasi diterapkan dalam pembelajaran maka peserta didik dengan sendirinya akan memiliki kompetensi dasar mengenai digital literasi. Para siswa tersebut selanjutnya membutuhkan pelatihan singkat untuk menggunakan peralatan digital yang lebih efisien untuk tujuan pembelajaran.

Menurut penelitian yang dilakukan oleh (Nair et al., 2012, p. 76), dengan sampel yang berasal dari negara semi urban dari negara Timur menunjukkan bahwa siswa yang mengalami peningkatan kemampuan digital literasi berasal dari orangtua yang melek komputer. Dalam pandangan Nair, semakin tinggi siswa yang memiliki kemampuan digital literasi maka semakin baik untuk masa depan bangsa. Sementara itu Jongsermtrakoon \& Nasongkhla (2015, p. 785) dalam penelitiannya juga mem-beri kesimpulan yang sama dengan Nair di atas, yaitu pembelajaran group investigation dapat meningkatkan pemahaman digital literasi siswa dan kesadaran etika informasi.

Dari sudut pandang yang berbeda, Zhang (2013, p. 50) menunjukkan bahwa dengan kemampuan digital literasi siswa dapat meningkatkan kemampuan bahasa Inggris di sekolah Cina Barat Laut. Dalam penelitiannya Zhang menemukan bahwa: (a) Guru dan siswa menunjukkan sikap positif terhadap pemanfaatan internet dalam proses belajar mengajar mata pelajaran Bahasa Inggris; (b) siswa memiliki pengetahuan tertentu tentang penggu- 
naan internet dalam pengajaran Bahasa Inggris dalam komunikasi sehari-hari; (c) siswa belum memiliki kemampuan mendalam tentang internet yang terintegrasi dengan pembelajaran; (d) pengetahuan guru dan siswa tentang komputer dan teknologi jaringan cukup terbatas sehingga untuk pengembangan lebih lanjut keduanya harus mengembangkan pembelajaran berbasis web.

Tuan Soh, Osman, \& Arsad (2012, p. 39) mengatakan bahwa digital literasi merujuk pada kemampuan menggunakan teknologi digital, peralatan komunikasi dan atau jaringan untuk akses, mengelola, mengkonsolidasikan, mengevaluasi, dan mencari informasi dalam pengetahuan masyarakat. Dengan kemampuan digital literasi siswa dapat membandingkan, membuat inferensi dan interpretasi, evaluasi dan memecahkan masalah dalam tugas-tugas yang diberikan kepada mereka dalam kehidupan sehari-hari. Tidak itu saja Zhang (2013, pp. 49-50) juga mengemukakan hasil temuannya bahwa dengan memanfaatkan internet siswa dapat meningkatkan kemampuan membaca, menulis, mendengarkan, berbicara, dan menerjemahkan. Siswa juga lebih mampu menggunakan internet bahasa Inggris, mengembangkan pelajararan berbasis web, mengerti perangkat lunak dan perangkat keras komputer, serta menggunakan blog dan email.

Hill, Wiley, Nelson, \& Han (2004, p. 443) juga berpendapat bahwa pembelajaran berbasis internet adalah perspektif yang dibangun oleh kaum konstruktivis. Efektivitas pembelajaran dengan teknologi adalah fungsi dari ketrampilan dan pemberian pengalaman siswa. Melalui hal tersebut kurikulum dirancang untuk menopang tujuan-tujuan pedagogis yang diinginkan.

Berdasarkan pendapat di atasdapat disimpulkan bahwa penelitian ini memperkuat pandangan kaum konstruktivistik yang meyakini bahwasiswaakan lebih memahami apa yang dipelajari dengan pengalaman langsung daripada hanya memperoleh penjelasan dari guru. Atau pembelajaran yang memanfaatkan lingkungan sosial memberi pembelajaran yang lebih bermakna pada siswa. Ini sesuai dengan pendapat Dewey (1916, p. 9), yang menulis bahwa tujuan adanya sekolah adalah agar pengalaman keseharian yang diperoleh anak dapat membuat mereka mampu tumbuh dan berkembang dalam situasi masyarakat di mana mereka hidup. Pandangan ini juga berke- sesuaian dengan pendapat Vygotsky yang sangat menekankan pentingnya peranan lingkungan kebudayaan dan interaksi sosial dalam perkembangan sifat-sifat dan tipe-tipe manusia (Slavin, 2005, p. 46).

\section{Penerapan Teori Konstruktivistik}

Berdasarkan hasil penelitian yang telah dikemukakan di atas, maka pada bagian ini akan dikemukakan temuan hasil penelitian yaitu sebagai berikut.

\section{Konsep Student Center}

Berdasarkan hasil penelitian tentang hasil belajar dan kemampuan digital literasi siswa menunjukkan bahwa keseluruhan aktivitas siswa dalam pembelajaran adalah efektif. Hal ini menunjukkan metode pembelajaran group investigation berbasis internet mengaktifkan siswa untuk berkomunikasi dan berinteraksi yang selanjutnya belajar lebih dalam. Selain itu juga dapat mengurangi dominasi guru dalam pembelajaran sehingga pembelajaran bersifat student center. Dengan berkurangnya dominasi guru siswa mempunyai banyak kesempatan untuk menyelesaikan tugas, mengungkapkan pendapat, menjawab pertanyaan dengan argumentasi maupun menanyakan sebuah pertanyaan.

Konsep student center dikarenakan penerapan pembelajaran group investigation juga dikemukakan oleh Zulkifli (n.d., p. 7-8), yaitu pertama, sebagian besar siswa menjadi lebih aktif dalam proses belajar mengajar. Kedua, sebagian besar siswa menjadi sangat termotivasi karena mereka tertarik dengan pembelajaran group investigation. Ketiga, siswa dilatih belajar kelompok dalam melakukan investigasi.

Sedangkan dalam pandangan John Dewey, konsep student center harus dikembangkan dalam pembelajaran karena menyebabkan perkembangan kognitif terhambat. Ia secara tegas mengkritik praktek pendidikan yang hanya menekankan pentingnya peranan guru dan mengesampingkan peranan para siswa. Dalam pendidikan harusnya selalu mengacu pada kebebasan dalam pelaksanaannya (Rostitawati, 2014, p. 135)..

Dewey mengadakan penelitiannya mengenai pendidikan di sekolah-sekolah dan mencoba menerapkan teori pendidikannya dalam praktek di sekolah-sekolah. Hasilnya, 
ia meninggalkan pola dan proses pendidikan tradisional yang mengandalkan kemampuan mendengar dan menghafal. Sebagai gantinya, ia menekankan pentingnya kreativitas dan keterlibatan siswa dalam diskusi dan pemecahan masalah (Rostitawati, 2014, p. 135).

Rostitawati (2014, p. 137) melanjutkan, sekolah sebagai lembaga penyelengara pendidikan menurut John Dewey harus mempunyai maksud dan tujuan untuk membangkitkan sikap hidup demokratis dan untuk memperkembangkannya. Hal ini harus dilakukan dengan berpangkal kepada pengalaman-pengalaman anak. Dengan demikian sekolah harus memberikan pengalaman-pengalaman yang bermanfaat bagi masa depan anak sekaligus juga anak dapat mengalaminya sendiri sebagai "bahan pelajaran", sehingga anak didik dapat menyelidiki, menyaring, dan mengatur pengalaman-pengalaman tadi.

Dengan demikian seorang guru harus menyediakan dua hal, pertama pengalaman bermakna dan fungsi sebagai mediator atau fasilitator. Oleh kerena itu, seorang guru memiliki tiga tugas utama yaitu: (a) Guru menyediakan pengalaman belajar yang memungkinkan siswa menyusun rancangan belajar. Seorang guru memungkinkan siswanya untuk menjalankan proses belajar atau membentuk pengertiannya sendiri. Yang perlu diperhatikan di sini adalah guru menyediakan pengalaman belajar bagi siswa itu sendiri. Mengajar dalam bentuk ceramah bukanlah menjadi tugas utama seorang guru; (b) Guru memberikan kegiatan-kegiatan yang membangkitkan rasa ingin tahu siswa dan membantu siswa untuk mengekspresikan gagasan-gagasannya atau mengkomunikasikan ide ilamiah mereka. Dengan kata lain, guru memberi semangat kepada siswa untuk berpikir, mencari pengalaman baru. Bahkan guru perlu memberikan pengalaman konflik. Pengalaman konflik yang dimaksudkan yakni pemaparan mengenai sebuah kasus atau persoalan yang perlu dipecahkan sendiri oleh siswa tersebut. Guru harus menyemangati siswa; (c) Guru memonitor atau mengevaluasi apakah proses berpikir siswa dan cara mengekspresikan pikiran berhasil atau tidak. Guru mempertanyakan apakah pengetahuan siswa cukup untuk memecahkan persoalan-persoalan yang akan dihadapi.

Dalam pandangan Vygotsky konsep student center atau guru berperan sebagai pembimbing dinamakan pemagangan kognitif (cognitive apprenticeship) (Yohanes, 2010, p. 128). Pemagangan kognitif mengacu pada proses di mana seseorang yang sedang belajar tahap demi tahap memperoleh keahlian melalui interaksinya dengan pakar. Pakar yang dimaksud di sini adalah orang yang menguasai permasalahan yang dipelajari. Jadi, dapat berupa orang dewasa atau kawan sebaya.

Memanfaatkan Lingkungan Digital Sebagai Sumber Belajar

Pembelajaran dengan memanfaatkan internet sebagai sumber belajar termasuk mengadaptasi perubahan zaman yang kini serba digital dengan cara yang positif. Menurut Vygotsky, setiap individu berkembang dalam konteks sosial di mana siswa tersebut berada. Keadaan sosial pada era ini adalah semakin berkembangnya media digital yang mengelilingi kehidupan sosial siswa dari berbagai tingkatan sekolah. Karenanya pembelajaran dengan memanfaatkan internet pada saat ini menjadi sesuatu yang harus dilakukan.

Pemanfaatan internet dalam pembelajaran bukan sekedar metode dalam investigasi pengetahuan namun menjadi kerangka kerja (framework) yang berhubungan erat dengan lingkungan sosial setiap siswa (Hill et al., 2004, p. 434). Saking pentingnya internet dalam dunia pendidikan dan pembelajaran, Kementerian Pendidikan Malaysia mencanangkan program Malaysia's Vision 2020:

"establish a scientific and progressive society, a high-power changes and look ahead, which is not only a consumer of technology but also a contributor to scientific and technological civilization" (Tuan Soh et al., 2012, p. 38).

(membangun masyarakat ilmiah dan progresif, dengan daya perubahan tinggi dan melihat ke depan, yang tidak hanya konsumen teknologi tetapi juga kontributor peradaban ilmiah dan teknologi)

Abad ini adalah abad digital. Sebagai produk globalisasi, internet harus dikuasai dan diberi muatan-muatan pembelajaran sehingga siswa memanfaatkannya dengan makna yang positif. Dengan memanfaatkan interent maka siswa abad ini akan memiliki keahlian, pengetahuan, dan sukses dalam pekerjaan dan kehidupannya (Tuan Soh et al., 2012, p. 39). 
Internet telah menjadi bagian sehari-hari dalam kehidupan siswa karena itu sebagaimana teori yang digunakan oleh Vygotsky bahwasannya dalam pembelajaran, faktor lingkungan sosial menjadi bagian yang integral.

Yohanes (2010, p. 129) menuliskan, dalam pandangan Vygotsky, semua kerja kognitif tingkat tinggi pada manusia mempunyai asal-usul dalam interaksi sosial setiap individu dalam konteks budaya tertentu. Atau dengan meminjam istilah Wilson dkk. (1993: p. 80), kognisi merupakan internalisasi dari interaksi sosial. Teori kognisi sosial dari Vygotsky ini mendorong perlunya landasan sosial yang baru untuk memahami proses pendidikan.

Senada dengan pendapat di atas, Olson dan Wisher (2002, p. 2) mengemukakan bahwa pembelaran berbasis web menawarkan siswa akses tak tertandingi untuk mendapatkan sumber daya instruksional melebihi jangkauan kelas konvensional. hal ini juga membuat pengalaman belajar lebih terbuka, fleksibel, interaktif, dan efisien.

Dalam penelitian ini pemanfaatan internet diikuti dengan penugasan berupa menulis ringkasan. Mengingat keadaan siswa SMP KHM. Nur yang belum pernah mendapatkan pelajaran mengenai komputer dan internet maka tugas tersebut cukup berat dilaksanakan. Dalam pandangan Vygotsky, perkembangan kemampuan siswa dapat dibedakan ke dalam dua tingkat, yaitu tingkat perkembangan aktual dan tingkat perkembangan potensial. Tingkat perkembangan aktual tampak dari kemampuan seseorang untuk menyelesaikan tugas-tugas atau memecahkan berbagai masalah secara mandiri. Sedangkan tingkat perkembangan potensial tampak dari kemampuan seseorang untuk menyelesaikan tugas-tugas dan memecahkan masalah ketika di bawah bimbingan orang dewasa atau ketika berkolaborasi dengan teman sebaya yang lebih kompeten.

Hasilnya siswa kelas eksperimen dan kelas kontrol mampu menyelesaikan tugas tersebut dengan baik. Dengan demikian tugas membuat rangkuman tersebut bagi siswa kedua kelas berada pada jangkauan kognitif siswa atau tugas-tugas tersebut berada pada $Z P D$. Di mana ZPD adalah jarak antara taraf perkembangan aktual, seperti yang nampak dalam pemecahan masalah secara mandiri dan tingkat perkembangan potensial, seperti yang ditunjukkan dalam pemecahan masalah di bawah bimbingan orang dewasa atau dengan bekerja sama dengan teman sebaya yang lebih mampu (Yohanes, 2010, p. 130).

Antara kemampuan digital literasi dengan pembelajaran internet memiliki hubungan yang kuat. Hal ini ditunjukkan dalam penelitian Nair et al. (2012, p. 77) yang menyimpulkan bahwa ada korelasi yang positif antara digital literasi dengan penggunaan internet. Berdasarkan uraian di atas maka dapat disimpulkan bahwa pemanfaatan internet dalam pembelajaran berhubungan kuat dengan meningkatnya kemampuan digital literasi siswa.

Penerapan pembelajaran group investigation berbasis internet dalam proses pembelajaran dapat meningkatkan hasil belajar siswa dan kemampuan digital iterasi siswa karena dalam model ini siswa belajar menyelidiki topik yang telah ditentukan guru secara kelompok sehingga tercipta suasana pembelajaran yang aktif dan menyenangkan. Sesuai dengan pendapat Height (Krismanto, 2003, p. 7) yang menyatakan to investigation berkaitan dengan kegiatan mengobservasi secara rinci dan menilai secara sistematis. Jadi investigasi adalah proses penyelidikan yang dilakukan seseorang, dan selanjutnya orang tersebut mengkomunikasikan hasil perolehannya, dapat membandingkannya dengan perolehan orang lain, karena dalam suatu investigasi dapat diperoleh satu atau lebih hasil. Dengan demikian akan dapat dibiasakan untuk lebih mengembangkan rasa ingin tahu. Hal ini akan membuat siswa untuk lebih aktif berpikir dan mencetuskan ide-ide atau gagasan, serta dapat menarik kesimpulan berdasarkan hasil diskusinya (presentasi) di kelas.

Model investigasi kelompok merupakan model pembelajaran yang melatih para siswa berpartisipasi dalam pengembangan sistem sosial dan melalui pengalaman, secara bertahap belajar bagaimana menerapkan metode ilmiah untuk meningkatkan kualitas masyarakat. model ini merupakan bentuk pembelajaran yang mengkombinasikan dinamika proses demokrasi dengan proses inquiry akademik. melalui negosiasi siswa-siswa belajar pengetahuan akademik dan mereka terlibat dalam pemecahan masalah sosial. dengan demikian kelas harus menjadi sebuah miniatur demokrasi yang menghadapi masalah-masalah 
dan melalui pemecahan masalah, memperoleh pengetahuan dan menjadi sebuah kelompok sosial yang lebih efektif.

Karena itu berdasarkan pendapat di atas dapat disimpulkan bahwa penganut paham konstrutivistik percaya siswa akan lebih memahami apa yang dipelajari melalui pengalaman langsung daripada hanya memperoleh penjelasan dari guru secara ceramah konvensional. Ini menekankan pada guru bahwa pendekatan yang pertamakali harus dilakukan membuat rencana rekayasa pengalaman yang bermakna dan menghubungkannya dengan materi pelajaran.

Presentasi Menaikkan Kemampuan Literasi Siswa

Dari hasil observasi diketahui bahwa terdapat persamaan dan perbedaan pada presentasi yang dilakukan kelas eksperimen dengan kelas kontrol. Persamaannya adalah kedua kelas sama-sama meningkat kemampuan literasinya yakni pada aspek menyampaikan materi, pengucapan/pelafalan bahasa Indonesia, kemampuan menjawab, kemampuan kerja sama dan ketelitian dalam mengumpulkan tugas membuat ringkasan.

Sedangkan perbedaannya adalah kelas eksperimen lebih unggul pada aspek kemampuan menjawab dan kemampuan kerja sama. Dua aspek keunggulan kelas eksperimen tersebut menunjukkan bahwa pembelajaran group investigation berbasis internet lebih bisa menguasai materi dan membentuk kerjasama antar anggota kelompok dibanding pembelajaran group investigation berbasis perpustakaan.

Presentasi merupakan tahap kelima dari enam tahap pada pembelajaran group investigation. Pada tahap ini siswa diberi kesempatan untuk mengaktualisasikan kemampuannya dalam menyampaikan materi, mendengar pertanyaan, dan menjawab pertanyaan secara argumentatif. Ini sesuai dengan apa yang dianjurkan Vygotsky bahwa siswa harus diberi kesempatan untuk menunjukkan potensi yang dimilikinya. Siswa harus diberi kesempatan untuk mencoba kegiatan secara mandiri karena tujuan utama pembelajaran kooperatif adalah setiap anggota kelompok memiliki pengetahuan dan ketrampilan untuk melakukan setiap aspek kegiatan secara mandiri (Doolittle, 1995, p. 23).

\section{Simpulan}

Berdasarkan hasil penelitian dan pembahasan yang diperoleh selama penerapan model pembelajaran group investigation berbasis internet pada pembelajaran IPS di kelas VIII A SMP KHM Nur Surabaya dapat disimpulkan sebagai berikut. Pertama, penerapan model pembelajaran group investigation berbasis internet dapat meningkatkan hasil belajar pada Tema Masa Pendudukan Jepang dan Persiapan Kemerdekaan Indonesia Mata Pelajaran IPS Kelas VIII di SMP KHM. Nur Surabaya, dengan rata-rata peningkatan 25,56. Sedangkan penerapan pembelajaran group investigation berbasis perpustakaan dapat meningkatkan hasil belajar siswa dengan ratarata peningkatan 19,91 . Ini menunjukkan bahwa penggunaan pembelajaran group investigation berbasis internet lebih efektif untuk meningkatkan hasil belajar siswa.

Kedua, penerapan model pembelajaran group investigation berbasis internet dapat meningkatkan kemampuan digital literasi siswa. Hal ini dtunjukkan dari hasil tes akhir (posttest) dan hasil tes kemampuan digital literasi. Dari hasil tes akhir kelas (posttest) kelas eksperimen mendapatkan skor rata-rata 75,8125 , sedangkan kelas kontrol sebesar rata-rata 67,375 . Sedangkan dari hasil tes kemampuan digital kelas eksperimen mendapatkan skor rata-rata 44, 5, sedangkan kelas kontrol sebesar rata-rata 29,8125.

Hasil dua tes di atas membuktikan bahwa pembelajaran group investigation berbasis internet lebih efektif dibanding pembelajaran group investigation berbasis perpustakaan terhadap peningkatan kemampuan digital literasi. Selain dua tes tersebut, kemampuan digital literasi siswa juga diukur melalui observasi. Hasil observasi menunjukkan nilai rata-rata kelompok eksperimen 91,6, sedangkan rata-rata kelompok kontrol 87. Hasil angket menunjukkan nilai rata-rata kelompok eksperimen 62, sedangkan rata-rata kelompok kontrol 55.

Berdasarkan temuan-temuan dalam penelitian ini, dalam rangka mencapai tujuan pembelajaran IPS yang tertuang dalam kurikulum maka dapat diajukan beberapa saran yaitu (1) untuk meningkatkan hasil belajar maka diperlukan variasi pembelajaran seperti penggunaan model cooperative learning tipe group investigation. Karena pembelajaran tipe 
ini relevan dengan karakteristik mata pelajaran IPS yang padat dengan konsep dan definisi. Melalui pembelajaran group investigation berbasis internet bisa dievaluasi dengan tiga ranah, kognitif, afektif, dan psikomotorik. Pada ranah kognitif, siswa dievaluasi melalui proses presentasi dan tanya jawab. Pada ranah afektif, siswa dievaluasi melalui kerjasama dan kekompakan dalam kelompok. Dan pada ranah psikomotorik, siswa dievaluasi melalui hasil karya yang berupa pembuatan ringkasan. Oleh karena itu untuk meningkatkan hasil belajar siswa yang dapat dilakukan sekolah dan guru yaitu dengan menggunakan pembelajaran group investigation berbasis internet. Karena dari perhitungan menunjukkan adanya peningkatan, maka disarankan untuk menggunaan pendekatan ini.(2) model pembelajaran group investigation berbasis internet berpengaruh juga terhadap peningkatan kemampuan digital literasi siswa dalam pembelajaran IPS. Oleh karena itu, untuk mengoptimalkan kemampuan digital literasi siswa harus terbiasa untuk memanfaatkan internet sebagai sumber belajar. Kemampuan digital literasi ini sangat diperlukan siswa pada tingkat SMP karena dengan demikian mereka mengadaptasi nilai-nilai positif dari era digital seperti sekarang.

\section{Daftar Pustaka}

Adam, S. (2014). Aplikasi teori perkembangan bahasa menurut Vygotsky dalam pendidikan. Tadbir: Jurnal Manajemen Pendidikan Islam, 2(2), 252-258. Retrieved from http://journal.iaingorontalo.ac.id/index.p $\mathrm{hp} / \mathrm{tjmpi} /$ article/view/252

Artini, Pasaribu, M., \& Husain, S. M. (2015). Penerapan model pembelajaran kooperatif tipe group investigation untuk meningkatkan aktivitas dan hasil belajar IPA pada siswa kelas VI SD Inpres 1 Tondo. Mitra Sains, 3(1). Retrieved from

http://jurnal.untad.ac.id/jurnal/index.php/ MitraSains/article/view/4135/3075

Doolittle, P. E. (1995). Understanding cooperative learning through Vygotsky's zone of proximal development.

Retrieved from files.eric.ed.gov/fulltext/ED384575.pdf
Hill, J. R., Wiley, D., Nelson, L. M., \& Han, S. (2004). Exploring research on Internetbased learning: from infrastructure to interactions. In D. H. Jonassen (Ed.), Handbook of research for educational communications and technology (2nd ed., pp. 433-460). New Jersey: Lawrence Erlbaum associates.

Jamrut, \& Aman. (2014). Peningkatan hasil belajar IPS melalui implementasi CTL metode GI berbantuan media SMP Negeri 6 Raha. Harmoni Sosial: Jurnal Pendidikan IPS, 1(2). https://doi.org/10.21831/HSJPI.V1I2.24 36

Jongsermtrakoon, S., \& Nasongkhla, J. (2015). A group investigation learning system for open educational resources to enhance student teachers' digital literacy and awareness in information ethics. International Journal of Information and Education Technology, 5(10), 783-788. https://doi.org/10.7763/IJIET.2015.V5.6 11

Mardapi, D. (2008). Teknik penyusunan instrumen tes dan nontes. Yogyakarta: Mitra Cendikia Press.

Nair, G. K. S., Rahim, R. A., Setia, R., Adam, A. F. binti M., Husin, N., Sabapathy, E., ... Seman, N. A. (2012). Terengganu schools extent of computer literacy and internet usage. Asian Social Science, 8(8), 74. Retrieved from http://www.ccsenet.org/journal/index.ph p/ass/article/view/18507/12270

Rostitawati, T. (2014). Konsep pendidikan John Dewey. TADBIR Jurnal Manajemen Pendidikan Islam, 2(2). Retrieved from http://download.portalgaruda.org/article. php? article $=293379 \& \mathrm{val}=6180 \&$ title $=\mathrm{K}$ ONSEP PENDIDIKAN JOHN DEWEY

Sulasti, N. W. (2013). Penerapan model pembelajaran kooperatif tipe Group Investigation (GI) untuk meningkatkan aktivitas dan hasil belajar siswa dalam pelajaran PKn di kelas XI IPA 1 SMA Negeri 1 Sawan tahun ajaran 2012/2013. Jurnal Jurusan Pendidikan PKn, 1(4). Retrieved from https://ejournal.undiksha.ac.id/index.php 


\section{/JJPP/article/view/616}

Tuan Soh, T. M., Osman, K., \& Arsad, N. M. (2012). M-21CSI: A validated 21st century skills instrument for secondary science students. Asian Social Science, 8(16), 38 .

https://doi.org/10.5539/ass.v8n16p38

Uno, H. B., \& Koni, S. (2012). Assesment Pembelajaran. Jakarta: Bumi Aksara.

Wibowo, K. P., \& Marzuki. (2015). Penerapan model make a Match berbantuan media untuk meningkatan motivasi dan hasil belajar IPS. Harmoni Sosial: Jurnal Pendidikan IPS, 2(2),
158-169.

https://doi.org/10.21831/HSJPI.V2I2.76 67

Yohanes, R. S. (2010). Teori Vygotsky dan implikasinya terhadap pembelajaran matematika. Jurnal Widya Warta, XXXIV(2), 854-1981.

Zhang, C. (2013). A study of internet use in EFL teaching and learning in Northwest China. Asian Social Science, 9(2), 48. https://doi.org/10.5539/ass.v9n2p48 